\title{
Seasonal changes in bruchid (Coleoptera: Chrysomelidae: Bruchinae) assemblages along managed highway ecotones*
}

\author{
ÁRPÁd SZENTESI ${ }^{1}$, ZoLtÁn GYÖRGY ${ }^{2}$, TIBOR JERMY ${ }^{3, * *}$ and BALÁZS KISS ${ }^{3}$ \\ ${ }^{1}$ Department of Systematic Zoology and Ecology, Loránd Eötvös University, Pázmány Péter sétány 1/C, Budapest, H-1117 \\ Hungary; e-mail: szentesi@caesar.elte.hu \\ ${ }^{2}$ Division of Strategy and Marketing, Hungarian Natural History Museum, Budapest, Baross utca 13, H-1088 Hungary; \\ e-mail: gyorgyzsizsik@gmail.com \\ ${ }^{3}$ Department of Zoology, Plant Protection Institute, Centre for Agricultural Research, Hungarian Academy of Sciences; Herman \\ Ottó út 15., H-1025 Hungary; e-mail: kiss.balazs@agrar.mta.hu
}

Key words. Chrysomelidae, Bruchinae, seasonal changes, road ecology, Fabaceae, introduced species, seed predation, host plant, guild

\begin{abstract}
Spring and summer composition and species richness of bruchid pre-dispersal seed predator assemblages associated with species of leguminous plants were monitored in a four-year non-experimental survey of 32 service areas along five highways in Hungary. The vegetation bands along highways (delimited by fences) were considered a special type of ecotone where herbaceous plants are exposed to regular mowing and therefore the composition of the vegetation there is very different from the adjacent vegetation. Altogether 57 herbaceous and woody species of leguminous plants were recorded at these sites, harbouring 20 autochthonous, 3 allochthonous, but established, and 4 recently introduced species of bruchid seed predators (Coleoptera: Chrysomelidae: Bruchinae). The species of leguminous plants recorded along highway verges during this project make up approximately one fourth of the Fabaceae in Hungary and of the bruchids ca. $80 \%$ (!) of the species known to occur in Hungary. At half of the service areas, mowing decreased the species richness of leguminous plants compared to that recorded prior to mowing, but not that of their bruchid seed predators. However, the species composition of the bruchid assemblages before and after mowing changed substantially. Null-model analyses indicated a random organization of spring assemblages and a deterministic one of summer assemblages of bruchids; very likely a result of host-specificity constraints. Calculations of host specificity confirmed the narrow host range recorded for bruchids that emerged from the samples of plants, in spite of new host records, such as three and two Trifolium species for Bruchidius picipes and Bi. sp. prope varius sensu Anton, respectively, Oxytropis pilosa for Bi. marginalis and Vicia cracca for Bruchus brachialis. Our results show that a surprisingly high number of species of bruchids occur in highway margins, however, the management of the vegetation there prevents a substantial portion of the native bruchid fauna establishing permanent populations.
\end{abstract}

\section{INTRODUCTION}

Community ecologists have long recognized the importance of gradual or abrupt changes in vegetation (ecotones) (Peters et al., 2009) for the distribution, diversity and trophic interactions of animal species. Transitional zones of vegetation such as in edges, borders, boundaries and margins are places where exchange of energy, materials and species take place within landscape mosaics (Risser, 1993; Pullin, 2002). Conservation studies exploring the manifold negative consequences of habitat destruction by fragmentation (Wiens et al., 1985; Cadenasso et al., 2003; Fagan et al., 2003; Strayer et al., 2003) inspired important conceptual and methodological developments. Habitat fragmentation and decrease leads to a plethora of direct and indirect effects. Sudden changes in vegetation structure at boundaries influence animal behaviour (Haddad, 1999; Schultz et al., 2012), alter mutualistic insect-plant interactions (Christianini \& Oliveira, 2013), may increase predation (Marini et al., 1995; Cantrell et al., 2002), modify decomposition rates vital to nutrient cycles (Didham, 1998) and affect abundance and community composition (Ewers \& Didham, 2008), etc.

Roads with their accompanying vegetation are a special type of artificial ecotone and frequent migratory or transportation routes of non-indigenous species. Road construction is one of the most conspicuous human contributions to

\footnotetext{
* This contribution is dedicated to the memory of Eszter Illyés (1979-2012), a young botanist, who commenced the botanical characterisation of the survey sites, however, whose unduly death ended a promising scientific carrier.

** Deceased (1917-2014).
} 
landscape fragmentation (van der Ree et al., 2011). Road ecology, a rapidly developing and new discipline (Forman et al., 2003), is concerned with the many kinds of effects roads (linear infrastructures) have on wildlife. Road ecology, however, overwhelmingly focuses on dangers to vertebrate populations and distribution, while data on invertebrates are scarce (Muñoz et al., 2015; but see Knapp et al., 2013).

The vegetation immediately adjacent to controlledaccess highways (thereinafter in the text: highways) is usually different from the surrounding landscape as it is mown at intervals. Highways are also often fenced to prevent larger animals accessing these areas. The area on either side of a highway affected by noise, pollution from vehicles, seed dispersal, etc., however, extends beyond the fence. The areas bordering on to highways are intentionally planted with fast growing species or those that prevent the erosion of slopes. Woody and herbaceous species of plants, not indigenous to Central Europe, make up 40\% of the vegetation growing along the sides of roads (Šerá, 2008) and form unusual associations. Therefore, these vegetation bands might provide habitats for introduced species of insects. Road ecotones, fully or in part, are also subject to major disturbances, i.e. regular mowing, which generate variation spatially and temporally (Wiens, 2000), decrease habitat heterogeneity and negatively affect species richness (Kruess \& Tscharntke, 2000).

The knowledge of non-native species of herbivorous insects, inadvertently carried and dispersed by vehicles is relatively poor. Along highways there are service areas at regular intervals where vehicles are stationary for long enough for any hitchhiker species to leave them and find a host plant. The first record of the spotted wing drosophila [Drosophila suzukii (Matsumura)] was first recorded in Hungary in 2012 at a service area (Kiss et al., 2013) and its repeated appearance in subsequent years (Lengyel et al., 2013) is a good example of the phenomenon. Kozár et al. (2013) record 22 species of scale insects new to the Hungarian fauna over a period of 10 years and postulate that a possible source is international transport. Matošević \& Živković (2013) list 98 non-native species of herbivorous insects in Croatia, a country bordering on Hungary in the south-west, supposedly introduced by trade, however, members of the coleopterous subfamily Bruchinae are not among them. While Roques \& Beenen (2010) report 14 species of seed beetles of 9 genera new to Europe, YusRamos et al. (2014) substantially expand this inventory by describing 42 species in 29 genera, among which there are 27 species belonging to 13 genera of Bruchini. As for Hungary, they list 11 established allochthonous species of Bruchinae. Seed predation might have an important effect on the population dynamics of the plants (Crawley, 2000; Szentesi \& Jermy, 2003).

The aim of this study was to record non-experimental evidence that the management of the vegetation growing alongside highways change the pattern of leguminous vegetation, and as a consequence, cause compositional changes in the associated herbivorous insect assemblag-

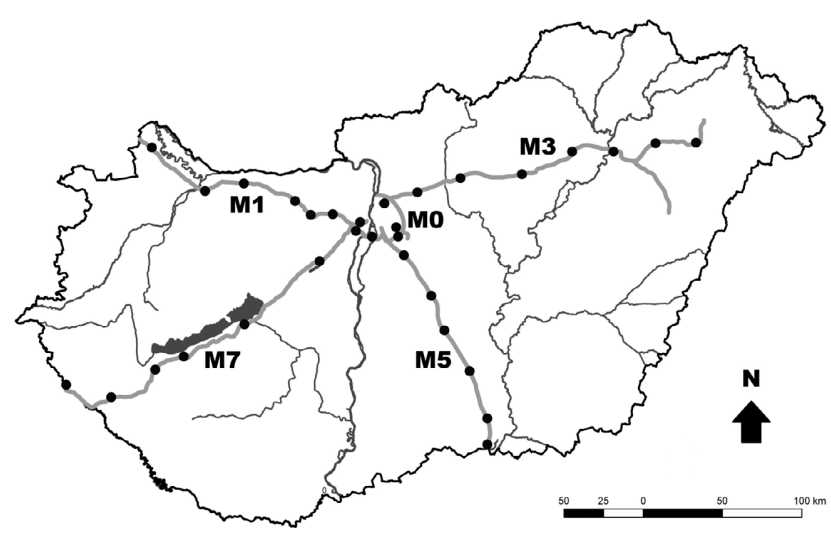

Fig. 1. Highways (grey bold lines) and service areas (black points) in Hungary where leguminous plants and bruchids were collected.

es. In addition, we sought evidence that transport along highways provides opportunities for non-native species of bruchids to become established. In order to achieve these aims, surveys were carried out with special focus on the presence or absence of leguminous plants and their bruchid seed predators. We did this by (a) creating an inventory of the species of leguminous plants and bruchids occurring at highway service areas; (b) comparing species richness and composition of the assemblages of leguminous plants and their bruchid seed predators before and after mowing at the same sites in subsequent years; and (c) checking for any non-native species of seed predators belonging to the subfamily Bruchinae feeding on leguminous plants.

\section{MATERIAL AND METHODS}

32 highway service areas (Fig. 1) were regularly surveyed for the occurrence of bruchid seed predators, including invasive species, along five highways in Hungary between 2011 and 2014. They included all the major soil and vegetation regions of the country. M0 (5 service areas) is still an incomplete circle around Budapest with great effects of urban areas on highway verges; M1 (6 service areas) is the highway that extends to the westernmost part of the country where the precipitation is higher than average; in contrast M3 (8 service areas) extends to the east where the climate and species are tinted with Eurasian characters; M5 (6 service areas) runs through sandy regions with the lowest precipitation where species from the Balkans occur; the south-western part of the M7 (7 service areas) is affected by adjacent sub-alpine effects and is where species from the Mediterranean occur. In the context of this paper the highways are transects through the country (Fig. 1).

It is emphasized that this study is not experimental. The leguminous plant and bruchid species richness before and after the first mowing were compared in the same areas subsequently; (a) before mowing by sweep-netting, (b) following mowing by collecting pods of leguminous plants, and (c) rearing bruchids from the pods.

\section{Description of sampling sites}

The service areas along the M0-M7 highways, with or without a filling station, are ca. 300 to $500 \mathrm{~m}$ long and 30 to $100 \mathrm{~m}$ wide with areas of grass planted with bushes (Berberis, Corylus, Cotoneaster, Crataegus, Ligustrum, Pyracantha, Rosa, Spirea, Symphoricarpus, Viburnum, etc.) and trees (Acer, Chamaecyparis, Fraxinus, Pinus, Populus, Pyrus, Quercus, Sorbus, Tilia, Ulmus, etc.), as well as having naturally growing herbaceous vegetation. 
All parts of the highways are fenced off from the surrounding area by a wire fence with a mesh of $15 \times 20 \mathrm{~cm}$. The central part of each service area is heavily affected by human activity, however, there is an additional peripheral larger "buffer zone" close to the fence in each case, where there are usually drainage ditches, or occasionally even a small pond, which is usually $1-3 \mathrm{~m}$ below the level of the rest of the area. The buffer zone is isolated from the rest of the area by steel safety barriers and visited only by maintenance and service personnel. Permission was obtained to survey and collect on all parts of the service areas.

\section{Survey of vegetation}

In May of 2011 each service area along the M0-M7 highways were surveyed to determine the general status of the vegetation (E. Illyés, unpubl.). The plant associations, species composition, and cover of species in $2 \times 2 \mathrm{~m}$ quadrates were recorded; the list of the species of plants present along two $20 \mathrm{~m}$ long transects, as well as the abundance of each species were recorded; any invasive/ non-native species of plant was noted. Altogether, there were 187 species of vascular plants recorded at the service areas. Cerastium spp., Plantago lanceolata, Poa angustifolia, Silene latifolia ssp. alba and Taraxacum officinale were the dominant species. In addition, in the quadrates and transects, there were $18.1 \pm 5.5(\mathrm{SD}$, $\mathrm{N}=36)$ species of other plants and $27.6 \pm 6.7(\mathrm{SD}, \mathrm{N}=34)$ species of leguminous plants. Characteristic grassland genera were: Bromus, Lolium, Festuca, Poa, Holcus, Potentilla, Medicago, Alopecurus, Plantago and Elymus. The leguminous species were identified by the first author. Several species of plants (e.g., Trifolium incarnatum on M7), not occurring naturally in the area, were extremely abundant at some, especially newly constructed sections of highways due to the sowing of imported seeds on the sloping roadsides in order to stabilize the soil. Likewise, rows of bushes of non-native species (e.g., Eleagnus umbellata, Pyracantha $\mathrm{sp}$.) planted on the slopes provided an important source of nectar for insects.

\section{Management of service areas}

The herbaceous vegetation along the highways and especially in the central part of each service area was usually mown to a height of ca. $5 \mathrm{~cm}$ twice during May-July. In addition, the buffer zones were also mowed at least once, together with the roadside slopes along the service roads leading in or out of the service areas. Mowing resulted in the removal of flowers or seed heads of herbaceous plants, especially the tallest species. Species of low stature or prostrate, such as Trifolium repens, T. hybridum, T. fragiferum, T. campestre/aureum, Medicago minima, Vicia lathyroides, etc. thrived under these conditions and individually occupied $0.5-1 \mathrm{~m}^{2}$, or even larger patches, mostly along drainage ditches and around tree trunks. Occasionally, mowing resulted in dwarf plants. Plant cuttings were removed from the area. There were always sites within the service areas where the mowing was incomplete. For instance, plants growing close to the fence remained intact and even were able to produce and mature seed, especially those using the fence as a support (e.g., Vicia villosa).

\section{Collection and processing of the samples of insects and plants}

The Palearctic bruchids (Coleoptera: Chrysomelidae: Bruchinae) that feed on members of the Fabaceae belong to the pre-dispersal seed predator guild and to the green-pod sub-guild (Szentesi \& Jermy, 1995), which include four major taxa: Bruchinae and Curculionidae (Coleoptera), species of microlepidoptera (Lepidoptera) and phytophagous chalcidoid wasps (Hymenoptera). The species in the green-pod sub-guild are narrowly host-specific on leguminous plants. Adult bruchids do not consume host tissue, but feed on pollen and nectar of flowering plants. They oviposit on immature pods containing only developing seeds. Almost all species of bruchids are univoltine and adults are not present in summer, because they die after several egg-laying sessions. The endophagous larval stadia complete their development in seeds. More than one guild member, of either species of bruchids, curculionids or Lepidoptera, might be present in pods of leguminous hosts. The curculionid and lepidopteran seed predators ectophagously consume seeds within pods.

Between 2011-2014 the presence/absence of leguminous species was recorded, bruchid adults were collected in May each year, and mature pods were sampled in July. In order to compare the composition and species richness of bruchid assemblages before mowing (in spring) and after mowing (in summer) two methods of collecting were used: (1) overwintered adults of bruchids were collected at each of the service areas surveyed along all the highways in the first or second, and again in the last week of May in all years. Adults were collected first by sweep-netting and beating nectar producing flowers of non-hosts (e.g. Lepidium draba, Eleagnus umbellata) and later from flowering and pod-producing hosts. A sweep-net of $40 \mathrm{~cm}$ diameter was used, and one sweepnetting session consisted of 50 strokes of ca. $1 \mathrm{~m}$ wide and $25 \mathrm{~m}$ long, $10-20 \mathrm{~cm}$ above ground level. There were up to a maximum of ten sweep-netting sessions at each service area depending on the size of the parking area and the availability of host plants. Surveys and collections were carried out with the same intensity at the different sites by spending approximately the same time (ca. $30 \mathrm{~min}$ ) at each service area. (2) Mature pods of herbaceous leguminous hosts were collected in July, and those of woody species in September in 2011-2013. One hundred heads or pods were collected from species of Trifolium and other leguminous species, respectively. All pods were collected if there were less than 100 and only 50 heads of $T$. pratense due to their large size.

Flower heads and individual pods were picked and placed in paper bags, then transferred to jars the openings of which were closed with linen cloth. The samples were kept outdoors. As adults usually emerge from infested pods in the same year, samples were checked from time to time until November of the same year in order to collect live adults. Samples were quantitatively evaluated after a final inspection the following year. Adults emerging from the samples were placed in $96 \% \mathrm{EtOH}$ and the species identified by the second author.

\section{Statistical methods}

Kruskal-Wallis ANOVAs were used to compare the numbers of species of both leguminous plants and bruchids, respectively, by years and highways. Species numbers on figures are medians and percentiles. For comparisons two-tailed tests were used. Leguminous plant species richness recorded in spring and summer along the same highways were compared using the Wilcoxon matched pairs test at $\mathrm{p}<0.05$ for two dependent samples. This pairwise comparison was necessary as there were at least one mowing session at the same sites between the two surveys. The Jaccard index (Magurran, 2004) was used to compare similarities in the composition of species of leguminous plants and bruchid assemblages, respectively, recorded before and after mowing in each year. Correlations (Pearson's r) between the number of species of leguminous plants and bruchids, respectively, before and after mowing were also calculated. For all computations the Statistica 6.0 program was used (StatSoft, 2003).

A null-model analysis was used to demonstrate significant species co-occurrences. Species co-occurrence refers to possible organizing forces, such as interspecific competition, or host plant specificity that are associated with communities with a particular composition (Gotelli \& Graves, 1996). Two presence/absence matrices needed for the null-model analysis were prepared: one 
for 16 species of bruchids captured at 32 service areas by sweepnetting, and one for 24 species of bruchids reared from samples of leguminous seed collected at 29 service areas. Species of the bruchid genus, Spermophagus, although regularly captured by sweep-netting, were not included in the analysis as they do not feed on leguminous plants. The observed and simulated matrices were compared following 10,000 randomization cycles, the minimum number of iterations suggested by Lehsten \& Harmand (2006), at the 0.05 probability level using the EcoSim700 program and sequential swap algorithm with fixed row and column sums (Entsminger, 2014). Significant co-occurrences of all possible species pairs were calculated using the C-score (Stone \& Roberts, 1990), which applied average "checkerboard (CS) units" according to the formula:

$$
C S=\frac{2 \sum_{i=1}^{S(S-1) / 2}\left(n_{i}-N_{i j}\right)\left(n_{j}-N_{i j}\right)}{S(S-1)}
$$

where $S$ is the number of species, $n_{i}$ and $n_{j}$ the number of occurrences (row totals) of the $i^{\text {th }}$ and $j^{\text {th }}$ species, and $N_{i j}$ is the number of co-occurrences of the two species. A Bayesian approach was used to detect false significant non-random associations of species using the Pairs program (Ulrich, 2008). If the samples contained mutually exclusive species-pairs one would expect the observed C-score to be significantly higher than the simulated one.

We determined the degree of host specificity of the bruchid assemblages reared from the samples of leguminous seed. The measure used was the multiple host dissimilarity index (Diserud \& Ødegaard 2007) based on May (1990), which indicates level of "effective specialization":

$E S=\frac{S_{P}}{\left(\bar{S}_{p} P\right)}$

where $E S$ is the measure of host specialization, $S_{P}$ is the number of species of bruchids associated with all the host plants, $\bar{S}_{P}$ is the average number of species of bruchids associated with one host, and $P$ is the number of species of plants. The denominator is in fact the number of all recorded connections between bruchids and host plants in the assemblages. This measure provides values between 0 (all bruchid species are "generalists") and 1 (all are monophagous). We also calculated the specialization of bruchids based on host records in Hungary (Jermy \& Szentesi, 2003) and for the Bruchus, Bruchidius and Megabruchidius genera collected, respectively, lumping together results for all years and service areas.

\section{RESULTS}

The species of leguminous plants recorded at 32 service areas along highways in Hungary are listed in Table 1. A total of 57 native and naturalized herbaceous and woody species of leguminous plants were recorded, which is approximately $1 / 4$ th of the species of the Fabaceae occurring in Hungary. Altogether 24 species of bruchids belonging to four genera were reared from samples collected at the service areas (Table 1). (See the authors' names of plant and insect species in the tables.)

\section{Comparing the numbers of species of leguminous plants}

\section{(1) Among service areas}

Sixteen species of plants were recorded at $50 \%$ of the localities (Table 1). These were either species frequently occurring at disturbed sites (Medicago sativa, M. lupulina, Trifolium pratense, T. repens), fugitive annuals (Vicia grandiflora, V. sativa ssp. nigra, V. villosa, Trifolium aureum/campestre, $T$. arvense, etc.), or species that tend to grow horizontally and as consequence are little affected by mowing, e.g. Astragalus austriacus, Medicago minima, T. hybridum and Vicia lathyroides. Seventeen species occurred only at 1-2 service areas. Forest edge species, such as Astragalus glycyphyllos, Lathyrus sylvestris, Trifolium alpestre, T. medium, Vicia pisiformis, V. sepium and $V$. tenuifolia occurred in very low numbers (one individual or patch). Several leguminous plant species (Trifolium repens, Vicia sativa ssp. nigra, V. grandiflora, V. pannonica ssp. pannonica, $V$. villosa), attacked by seed eating insects, formed continuous and large $\left(>100 \mathrm{~m}^{2}\right)$ patches and frequently grew intermingled. Sometimes a single patch $(O x-$ ytropis pilosa), or a single individual (Trigonella caerulea) was present, in spite of the regular and heavy disturbance.

\section{(2) Among highways and years}

Spring and summer surveys of species of leguminous plants. There were no significant differences in the median numbers of species of leguminous plants recorded in spring or summer along the different highways (spring: $\mathrm{H}_{4 ; 128}=7.21 ; \mathrm{p}=0.1250$, summer: $\left.\mathrm{H}_{4 ; 96}=4.19 ; \mathrm{p}=0.3809\right)$. Comparison by years revealed differences in spring $\left(\mathrm{H}_{3 ; 128}\right.$ $=16.23, \mathrm{p}=0.001)$, but not in summer $\left(\mathrm{H}_{2 ; 96}=1.45 ; \mathrm{p}=\right.$ 0.4849 ), due to the significantly lower number of species recorded in 2012 and 2014. Among-highway comparisons for all years in May indicated the same species richness of leguminous plants everywhere: $\mathrm{M} 0: \mathrm{H}_{3 ; 20}=3.19 ; \mathrm{p}=$ $0.3633 ; \mathrm{M} 1: \mathrm{H}_{3 ; 24}=5.81 ; \mathrm{p}=0.1214 ; \mathrm{M} 3: \mathrm{H}_{3 ; 32}=6.17 ; \mathrm{p}$ $=0.1035 ; \mathrm{M} 5: \stackrel{\mathrm{H}}{3 ; 25}=3.21 ; \mathrm{p}=0.3601 ; \mathrm{M} 7::_{3 ; 27}=5.11$; $\mathrm{p}=0.1637$. Similarly, there were no differences in species richness in July: $\mathrm{M} 0: \mathrm{H}_{2 ; 15}=0.01 ; \mathrm{p}=0.9923 ; \mathrm{M} 1: \mathrm{H}_{2 ; 18}=$ $0.59 ; \mathrm{p}=0.7449 ; \mathrm{M} 3: \mathrm{H}_{2 ; 24}=1.51 ; \mathrm{p}=0.4698 ; \mathrm{M}^{2} \mathrm{H}_{2 ; 19}=$ $1.96 ; \mathrm{p}=0.3744 ; \mathrm{M} 7: \mathrm{H}_{2 ; 20}=4.01 ; \mathrm{p}=0.1345$. All differences were computed using Kruskal-Wallis ANOVA and multiple comparisons.

\section{(3) Before and after mowing}

Pairwise comparisons of the species richness of leguminous plants at the same service area in spring (pre-mowing) and summer (post-mowing) revealed significant differences in 2011 and 2013, but not in 2012 (Fig. 2). Mowing decreased the species richness of leguminous plants in all years: 2011: $\mathrm{N}=32, \mathrm{Z}=3.8520, \mathrm{p}<0.001 ; 2012: \mathrm{N}=32$, $\mathrm{Z}=0.0240, \mathrm{p}=0.9808 ; 2013: \mathrm{N}=32, \mathrm{Z}=3.0479, \mathrm{p}=$ 0.0023; and along all highways: $\mathrm{N}=96, \mathrm{Z}=4.2745, \mathrm{p}<$ 0.001 (Wilcoxon matched pairs test at $\mathrm{p}<0.05$ ). In spite of this, the Jaccard similarity index of the species composition before and after mowing was very similar: 0.68 in 2011, 0.72 in 2012 and 0.80 in 2013 (all highways and service areas included). The number of species of leguminous plants before and after mowing were positively correlated: $\mathrm{N}=96, \mathrm{r}=0.3825, \mathrm{p}<0.001$. 
Table 1. List of leguminous plants and species of bruchids recorded in highway ecotones in Hungary.

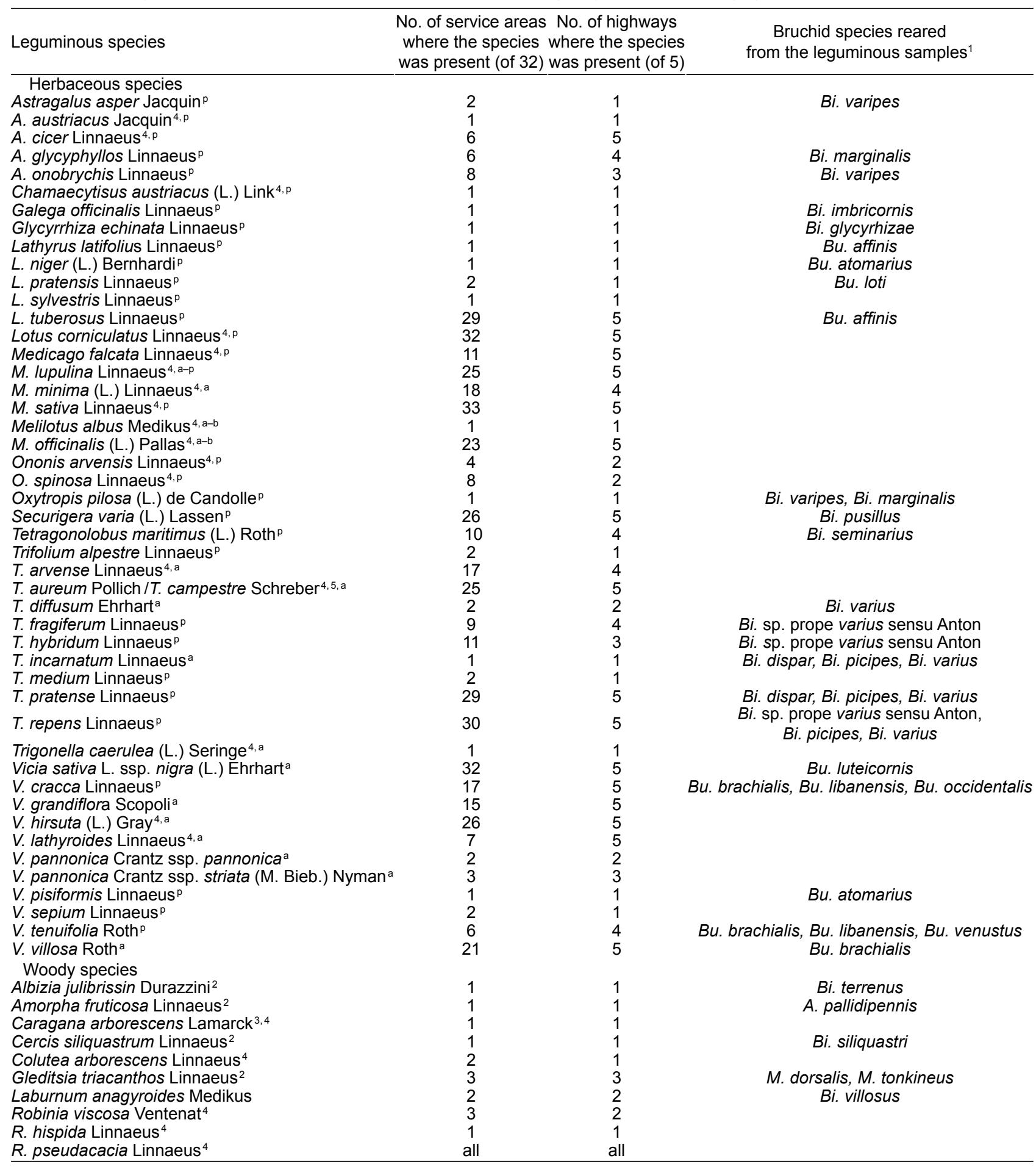

${ }^{1}$ In summary 35 autochthonous and 5 non native bruchid species were recorded, however some inhabit more than one leguminous host. Bu. - Bruchus, Bi. - Bruchidius, M. - Megabruchidius, A. - Acanthoscelides. ${ }^{2}$ Designate those legume species that harbour introduced/ invasive bruchid species. ${ }^{3}$ Marks possible host-shift of an unknown bruchid species. ${ }^{4}$ Marks those legumes that do not harbour bruchid species in Hungary. ${ }^{5}$ Could not be separated at site. a annual, ${ }^{a-b}$ annual-biennial, ${ }^{\mathrm{p}}$ perennial plant species. Scientific names accepted are those used in the databases of the Royal Botanical Garden of Edinburgh (http://www.rbge.org.uk/) and The Plant List (http://www. theplantlist.org/).

\section{Number of species and similarity of the bruchid assemblages}

Altogether ca. 3,000 individuals belonging to 29 species of the Bruchinae subfamily [ca. $80 \%$ of the Hungarian bruchid fauna; György \& Merkl (2005)] were captured by sweep-netting plants and/or by rearing them from samples of leguminous plants. Of the 29 species, 10 were species of Bruchus (henceforth abbreviated as Bu.), 13 of Bruchidius (henceforth abbreviated as Bi.), 2 of Megabruchidius, 1 of Acanthoscelides and 3 of Spermophagus (Table 2). Sixteen species of bruchid that feed on leguminous plants were captured by sweep-netting. Based on the samples of 


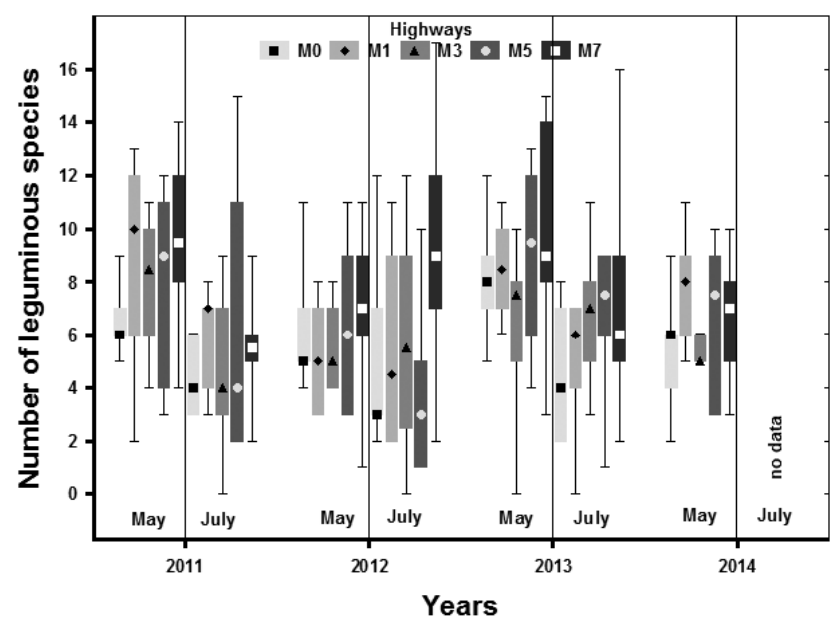

Fig. 2. The number (median, $25-75 \%$ percentiles and min-max) of species of leguminous plant recorded at highway service stations in spring (pre-mowing in May) and summer (post-mowing in July). Highways where the species richness of leguminous plants was significantly lower after mowing are highlighted. In 2011: M0: $N=5$, $Z=1.62, p=0.1056 ; \mathbf{M} 1: N=6, Z=1.99, p=0.0460 ; \mathbf{M} 3: N=8, Z$ $=2.52, p=0.0117 ; M 5: N=6, Z=0.52, p=0.6002 ; M 7: N=7, Z=$ 2.37, $p=0.018$; in 2012: $M 0: N=5, Z=0.81, p=0.4185$; $M 1: N=$ $6, Z=0.13, p=0.8927 ; M 3: N=8, Z=0.21, p=0.8339 ;$ M5: $N=6$, $Z=1.78, p=0.075 ; \mathbf{M 7}: N=7, Z=2.02, p=0.0431$; in 2013: $\mathbf{M 0}$ : $N=5, Z=2.02, p=0.0431 ; M 1: N=6, Z=2.20, p=0.0277 ; M 3$ $\mathrm{N}=8, \mathrm{Z}=0.42, \mathrm{p}=0.6744 ; \mathrm{M} 5: \mathrm{N}=6, \mathrm{Z}=1.47, \mathrm{p}=0.1422 ; \mathrm{M} 7$ $\mathrm{N}=7, \mathrm{Z}=1.44, \mathrm{p}=0.1508$. (Pairwise comparisons using Wilcoxon matched pairs test at $p<0.05$.) leguminous plants collected, bruchids were recorded on 35 $(61.4 \%)$ of the 57 species of leguminous plants, and eight harboured more than one species of bruchid (Table 1). Of the 35 species of leguminous plants four woody species harboured five invasive bruchid species and 32 native herbaceous species of leguminous plants harboured autochthonous bruchids.

\section{(1) Among service areas}

Bruchids did not inhabit 53\% (9 out of the 17) of the most common species of leguminous plants occurring along the highways sampled (Table 1). The remaining eight species either harboured "broadly" oligophagous bruchids, such as $B u$. affinis, or ubiquitous specialists, like Bu. luteicornis, $B u$. brachialis, Bi. pusillus and Bi. varius. The most frequent species of bruchids collected by sweep-netting were $B u$. brachialis and Bu. luteicornis (present at $62.5 \%$ and $53.1 \%$ of the service areas, respectively). Whereas the former was usually recorded during the flowering of its host plant, the latter was present even before flowers appeared. Several species (Bu. brachialis, Bu. affinis, Bi. varius and Bi. pusillus) were frequent at 8-10 service areas based on rearing them from seed samples.

\section{(2) Among highways}

Collection by sweep-netting and rearing from samples of plants. There were no significant differences in the median number of species of bruchids collected either

Table 2. List of bruchid species recorded in highway ecotones in Hungary.

\begin{tabular}{|c|c|}
\hline Collected by sweep-netting & Reared from legume seed samples \\
\hline Genus: Acanthoscelides Schilsky, 1905 & Genus: Acanthoscelides \\
\hline Acanthoscelides pallidipennis (Motschulsky, 1874) ${ }^{1}$ & Acanthoscelides pallidipennis \\
\hline Genus: Bruchidius Schilsky, 1905 & $\begin{array}{l}\text { Genus: Bruchidius } \\
\text { Bruchidius dispar (Gyllenhal, 1833) } \\
\text { Bruchidius glycyrhizae (Fåhraeus, 1839) }\end{array}$ \\
\hline Bruchidius imbricornis (Panzer, 1795) & $\begin{array}{l}\text { Bruchidius imbricornis } \\
\text { Bruchidius marginalis (Fabricius, 1775) }\end{array}$ \\
\hline Bruchidius picipes (Germar, 1824) & Bruchidius picipes \\
\hline Bruchidius pusillus (Germar, 1824) & Bruchidius pusillus \\
\hline Bruchidius seminarius (Linnaeus, 1767) & $\begin{array}{l}\text { Bruchidius seminarius } \\
\text { Bruchidius siliquastri Delobel } 2007^{3}\end{array}$ \\
\hline Bruchidius sp. prope varius sensu Anton & $\begin{array}{l}\text { Bruchidius sp. prope varius sensu Anton } \\
\text { Bruchidius terrenus (Sharp, 1886) } \\
\text { Bruchidius varipes (Boheman, 1839) }\end{array}$ \\
\hline Bruchidius varius (Olivier, 1795) & Bruchidius varius \\
\hline Bruchidius villosus (Fabricius, 1792) & Bruchidius villosus \\
\hline $\begin{array}{l}\text { Genus: Bruchus Linnaeus, } 1767 \\
\text { Bruchus affinis Frölich, } 1799\end{array}$ & $\begin{array}{l}\text { Genus: Bruchus } \\
\text { Bruchus affinis } \\
\text { Bruchus atomarius (Linnaeus, 1761) }\end{array}$ \\
\hline $\begin{array}{l}\text { Bruchus brachialis (Fåhraeus, 1839) } \\
\text { Bruchus libanensis Zampetti, } 1993\end{array}$ & $\begin{array}{l}\text { Bruchus brachialis } \\
\text { Bruchus libanensis } \\
\text { Bruchus loti Pavkull } 1800\end{array}$ \\
\hline $\begin{array}{l}\text { Bruchus luteicornis Illiger, } 1794 \\
\text { Bruchus occidentalis Lukjanovits et Ter-Minassian, } 1957 \\
\text { Bruchus pisorum (Linnaeus, 1758) } \\
\text { Bruchus rufimanus Boheman, 1833 }\end{array}$ & $\begin{array}{l}\text { Bruchus luteicornis } \\
\text { Bruchus occidentalis }\end{array}$ \\
\hline $\begin{array}{l}\text { Bruchus venustus (Fåhraeus, 1839) } \\
\text { Genus: Megabruchidius Borowiec, } 1984\end{array}$ & $\begin{array}{l}\text { Bruchus venustus } \\
\quad \text { Genus: Megabruchidius } \\
\text { Megabruchidius tonkineus (Pic, 1904) } \\
\text { M. dorsalis (Fåhraeus, 1839) }\end{array}$ \\
\hline $\begin{array}{l}\text { Genus: Spermophagus Schönherr, } 1833 \\
\text { Spermophagus calystegiae (Lukjanovits et Ter-Minassian, 1957) } \\
\text { S. sericeus (Geoffroy, 1785) } \\
\text { S. sp. }{ }^{2} \text { (not identified) }\end{array}$ & \\
\hline
\end{tabular}

${ }^{1}$ Allochthonous originally, but became established. ${ }^{2}$ Marks bruchid species inhabiting non-leguminous plant species. ${ }^{3}$ Designates recently introduced/invasive bruchid species. 


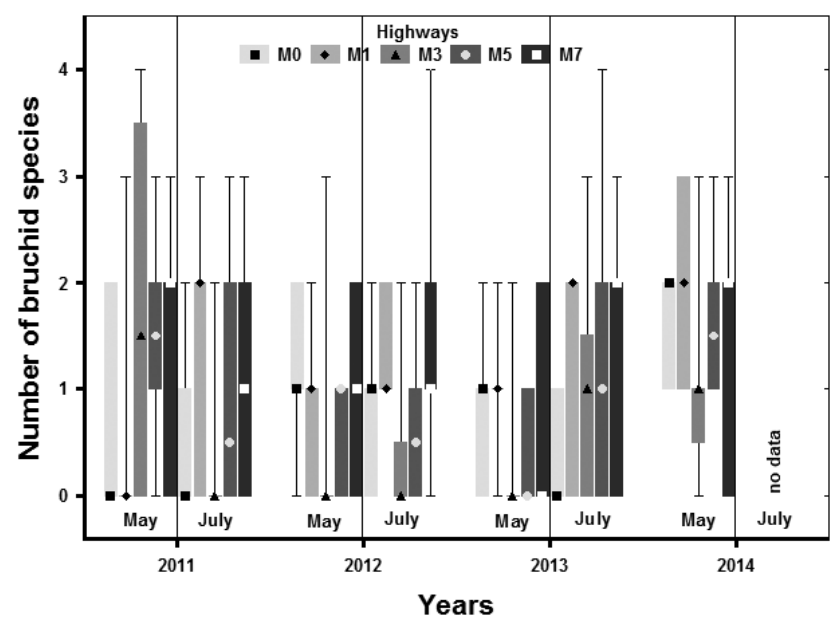

Fig. 3. The number (median, 25-75\% percentiles and min-max) of species of bruchids collected by sweep-netting in spring (premowing in May) and reared from samples of leguminous plants collected in summer (post-mowing in July). The comparisons of species numbers among years along the same highways were done using Kruskal-Wallis ANOVA and multiple comparisons. For the pre-mowing in May: $M 0: H_{3 ; 20}=2.88 ; p=0.4104 ; M 1: H_{3 ; 24}=7.64 ; p$ $=0.0540 ; M 3: H_{3 ; 31}=7.88 ; p=0.0485 ; M 5: H_{3 ; 20}=7.22 ; p=0.0653$; M7: $\mathrm{H}_{3 ; 28}=3.89 ; \mathrm{p}=0.2740$ and post-mowing in July: $M 0: \mathrm{H}_{2 ; 15}=$ $0.63 ; p=0.7284 ; M 1: H_{2 ; 18}=0.34 ; p=0.8429 ; M 3: H_{2 ; 24}=4.09 ; p=$ $0.1291 ; M 5: H_{2 ; 18}=0.60 ; p=0.7400 ; M 7: H_{2 ; 21}=0.76 ; p=0.6844$.

by sweep-netting or rearing, respectively, recorded for highways in all years (Fig. 3), or for highways alone (collected: $\mathrm{H}_{4 ; 123}=3.48 ; \mathrm{p}=0.4817$; reared: $\mathrm{H}_{2 ; 96}=1.76 ; \mathrm{p}=$ 0.4154). However, considering all highways, significantly more bruchid adults were collected in 2014 than in 2012 or $2013\left(\mathrm{H}_{3 ; 123}=14.25 ; \mathrm{p}=0.0026\right)$. Multiple comparisons of the highways by years revealed significant heterogeneity $\left(\mathrm{H}_{4: 96}=11.59 ; \mathrm{p}=0.0207\right)$, however, no pairwise difference was recorded in the number of bruchid adults that emerged from samples. All these differences were computed using Kruskal-Wallis ANOVA and multiple comparisons.

\section{(3) Similarity of the species composition of bruchid assemblages}

Of the species of bruchid collected by sweep-netting in spring and reared from samples of plants collected in summer $58.3 \%$ were recorded in all years and for all highways. The similarity in the composition of species in bruchid assemblages in spring and summer was low. The Jaccard similarity indices for the number of species collected and reared in common in spring and summer were: 0.25 in 2011, 0.35 in 2012 and 0.26 in 2013 (all highways and service areas included). The number of species of bruchids collected in spring and reared from the samples of plants were not correlated: $\mathrm{N}=93, \mathrm{r}=0.0313, \mathrm{p}=0.7650$.

\section{(4) Null-model analyses of bruchid assemblages}

There were no significant co-occurrences of bruchids in the spring assemblage collected by sweep-netting. The observed C-score index was 8.48, whereas the simulated one was $8.42(p=0.3965)$. However, for the assemblage reared from leguminous host plants the observed and simulated $\mathrm{C}$-scores were close to the expected probability level $(\mathrm{p}=$
$0.05): 7.025$ and 6.868 , respectively $(p=0.0760)$, i.e. there were indications of bruchid co-occurrences.

\section{Host plant specificity}

Table 3 provides information about the host affiliation and relative abundance of species of bruchids reared from samples of leguminous plants collected along the highways. The multiple host dissimilarity index $(E S)$ for all the species of bruchids reared was 0.60 , indicating that the majority of the species were specialists. The species of Bruchus had altogether 13 insect-host plant connections and an $E S$ of 0.62. For those of Bruchidius it was 24 insect-plant interactions and an ES of 0.54, whereas it was 2 and an ES $=1$ for those of Megabruchidius. On the basis of published host records (Jermy \& Szentesi, 2003), among the 28 species of bruchids recorded there was only one Bruchus and 10 Bruchidius that were monophagous, and the index was 0.42 , indicating a high percentage of "generalists". New host records include Trifolium pratense, T. repens and $T$. incarnatum for Bi. picipes, T. repens and T. hybridum for $B i$. species prope varius sensu Anton, Oxytropis pilosa for Bi. marginalis and Vicia cracca for Bu. brachialis (Table 1), i.e., 4, 3, 2 and 3, more hosts, respectively, than recorded by Jermy \& Szentesi (2003). This indicates changes in the host specificity of Bi. picipes, Bi. species prope varius

Table 3. Host plant specificity and relative abundance of species of bruchids reared from the leguminous samples collected at service stations.

\begin{tabular}{|c|c|c|c|}
\hline Bruchid species $^{1}$ & $\begin{array}{l}\text { No. of hosts } \\
\text { recorded in } \\
\text { this study }{ }^{2}\end{array}$ & $\begin{array}{l}\text { No. of } \\
\text { hosts } \\
\text { known }{ }^{3}\end{array}$ & $\begin{array}{c}\text { Relative } \\
\text { abundance }^{4}\end{array}$ \\
\hline \multicolumn{4}{|l|}{ Genus: Acanthoscelides } \\
\hline \multicolumn{3}{|l|}{ Genus: Bruchidius } & $>1000$ \\
\hline Bruchidius dispar ${ }^{\circ}$ & 2 & 2 & 3 \\
\hline Bruchidius glycyrhizae ${ }^{\mathrm{m}}$ & 1 & 1 & 82 \\
\hline Bruchidius imbricornis $^{\mathrm{m}}$ & 1 & 1 & 885 \\
\hline Bruchidius marginalis $^{\circ}$ & 2 & 1 & 3 \\
\hline Bruchidius picipes ${ }^{\circ}$ & 3 & 1 & 10 \\
\hline Bruchidius pusillus ${ }^{\mathrm{m}}$ & 1 & 1 & 97 \\
\hline Bruchidius seminarius ${ }^{\mathrm{m}}$ & 1 & 1 & 82 \\
\hline Bruchidius siliquastrim & 1 & 1 & 155 \\
\hline Bruchidius sp. prope varius & 3 & 1 & 253 \\
\hline Bruchidius terrenus $^{\mathrm{m}}$ & 1 & 1 & 52 \\
\hline Bruchidius varipes $^{\circ}$ & 3 & 5 & 32 \\
\hline Bruchidius varius $^{\circ}$ & 4 & 5 & 78 \\
\hline Bruchidius villosus ${ }^{\circ}$ & 1 & 9 & 42 \\
\hline \multicolumn{4}{|l|}{ Genus: Bruchus } \\
\hline Bruchus affinis $^{\circ}$ & 2 & 4 & 194 \\
\hline Bruchus atomarius $^{\circ}$ & 2 & 9 & 49 \\
\hline Bruchus brachialis $^{\circ}$ & 3 & 2 & 162 \\
\hline Bruchus libanensis $^{\circ}$ & 2 & 2 & 19 \\
\hline Bruchus lotio & 1 & 2 & 16 \\
\hline Bruchus luteicornis $^{\circ}$ & 1 & 2 & 35 \\
\hline Bruchus occidentalis $^{\circ}$ & 1 & 2 & 40 \\
\hline Bruchus venustus $^{\circ}$ & 1 & 2 & 22 \\
\hline \multicolumn{4}{|l|}{ Genus: Megabruchidius } \\
\hline Megabruchidius tonkineus ${ }^{\mathrm{m}}$ & 1 & 1 & $>100$ \\
\hline Megabruchidius dorsalis ${ }^{\mathrm{m}}$ & 1 & 1 & $>100$ \\
\hline
\end{tabular}

${ }^{1}$ See authors' names in Table 2. ${ }^{2}$ Number of leguminous plant species from which the bruchid species was reared in this study. ${ }^{3}$ Based on $>20$ years of collection of leguminous plant samples in Hungary (Jermy \& Szentesi, 2003). ${ }^{4}$ Number of bruchid individuals reared from samples collected in this study. ${ }^{\mathrm{m}}$ monophagous, ${ }^{\circ}$ oligophagous species. 
sensu Anton and Bi. marginalis from mono- to oligophagous, whereas $\mathrm{Bu}$. brachialis remains oligophagous.

\section{Introduced species of bruchids}

During the four-year survey, seven non-native species of bruchids were recorded (Table 2). Three of these (Acanthoscelides pallidipennis, Bruchus pisorum and Bu. rufimanus) became established in the $20^{\text {th }}$ century and are currently naturalized, four others (Megabruchidius tonkineus, M. dorsalis, Bi. siliquastri and Bi. terrenus) must have been introduced in the early 2000s (see Discussion).

\section{DISCUSSION}

Highways are a special type of ecotone. Unlike the borders of natural vegetation that may grade into the adjacent landscape mosaic at different scales (Gosz, 1993), highway ecotones are larger, more homogeneous, and most of all, artificial. Ecotones mediate species and effects. There are no natural successional changes due to the almost continuous management (mowing). As a consequence, the species of plants present must be able to tolerate regular disturbance and still be able to produce propagules, or equipped with effective dispersal and colonization mechanisms.

In this study we found that the host plants of bruchids are either fugitive annuals having seed banks, such as Vicia grandiflora, $V$. sativa ssp. nigra (Szentesi \& Jermy, 2003) or low-stature perennials (Tetragonolobus maritimus, Trifolium fragiferum, T. hybridum and T. repens) (Table 1). Both groups form patches at service areas and the latter are able to re-sprout in spite of regular mowing. There were no significant differences in the median number of species of leguminous plants in the different years or along different highways either in spring or summer, respectively, with the exception of a lower number of species in the springs of 2012 and 2014. It is assumed that the general lack of a difference is the result of the presence of a dozen ubiquitous species of leguminous plants such as Lathyrus tuberosus, Medicago sativa, M. lupulina, M. minima, Securigera varia, Trifolium campestre/aureum, T. pratense, T. repens, Vicia sativa ssp. nigra, $V$. grandiflora and $V$. villosa along almost all highways and in service areas. These species either grow from seeds, re-sprout after the first mowing (second half of May) or survive in small patches. This is also supported by the high compositional similarity between years as measured by the Jaccard index. In contrast, pairwise comparisons indicate a ca. 50\% decrease in the number of species of leguminous plants following mowing (Fig. 2) indicating that, in general, mowing could decrease the species richness of leguminous plants.

\section{Bruchid assemblages}

We found supporting evidence for the hypothesis that a very high percentage of the bruchid fauna would be recorded in the service areas along the highways (Table 2) in spite of the intensive mowing. However, the compositional similarities (measured by the Jaccard index) of the assemblages collected by sweep-netting versus those reared from collected samples of pods were low in certain years and the numbers of species were not correlated (first part of hypothesis b). The median number of species of bruchids did not differ among highways or years (Fig. 3), but significantly more species was collected in the spring of 2014 than during the same period in other years. The lack of differences in the numbers of species could be attributed to the consistent presence of 4-6 species of leguminous plants (listed above) that harboured bruchid species.

Our results confirmed that for the spring and summer assemblages of bruchids different assembly rules apply (second part of hypothesis b). (1) Adults of actively dispersing species of bruchids congregate on nectar-producing plants (e.g., Eleagnus umbellata, Lepidium draba, etc.) in spring when their host plants are not present or pods are not yet available for oviposition. The very low compositional similarities to the summer assemblages and the lack of significance of co-occurrences revealed by the nullmodel analysis provide further support for the spring assemblages being formed at random by dispersal from the surrounding areas to the highway ecotones. (2) From the samples of summer pods, however, only those members of the spring assemblages were reared, whose hosts were present at egg-laying and produced mature pods in spite of mowing. The compositional difference between the spring and summer bruchid assemblages is greater if fewer host plants remain following mowing. Thus, it is the availability of leguminous plants at the service areas that determines the composition of bruchid assemblages in summer. This implies that the narrow host-specificity of the insect seed predators is the ultimate constraint in the structuring the summer assemblages, regulates co-occurrences, determines guild membership (Jermy \& Szentesi, 2003; Szentesi et al., 2006), and also makes the composition of the summer assemblage more predictable (see more on this below). Indeed, the null-model analysis indicated that this could be the case. The nearly significant $\mathrm{C}$-score probably is both the consequence of the presence of several taxonguilds [complying with close phylogenetic relatedness of members (Schoener, 1986)] feeding on the eight species of leguminous hosts (Table 1) and the occurrence of curculionid and lepidopterous seed predators in the same samples. However, competition, which is generally thought to be a structuring force, might be involved in the formation of the seed predator guilds. There are similar results recorded for phytophagous insects feeding on cruciferous plants, where plant chemistry characteristic of Brassicaceae (an host-associated constraint) is hypothesized as an organizing force by Frenzel \& Brandl (1998), irrespective of the feeding guilds.

The lack of significant differences between the species richness of bruchids in spite of the regular removal of above-ground vegetation, and the low similarity of the composition of the species of bruchids in spring and summer assemblages, are possibly both due to the way this community is organized. The long-standing and unsettled dispute over the nature of forces organizing assemblages, guilds and communities still divides ecologists (Weiher \& Keddy, 1999). Assembly rules depend on the communities; some are a result of competition (Brown, 1987) others 
assemble by chance (Simberloff et al., 1999). Moreover, taxon-guilds, with high host specificity, produce mandatory guilds. Such guilds are recorded for tephritid flies (Zwölfer, 1988), hispine beetles (Strong, 1982) and some species of bruchids (Szentesi et al., 2006).

\section{Host range and specificity}

As for the host specificity of members of the subfamily Bruchinae, we refer to Jermy \& Szentesi (2003) who provide detailed information on the subject. Their study was based on decades of collecting several thousand samples of leguminous seed and recording the beetles that emerged. Based on this information, the members of the subfamily Bruchinae subfamily recorded in our study are either mono- or oligophagous, and although new host records were added (Tables 1 and 3, and see Results), they did not change the overall status of the host specificity of the bruchids. A monophagous species feeds only on a single plant species and an oligophagous species feeds on several (but not in all) members of a plant family, in the present case Fabaceae. Although host specificity is genetically determined, these terms are conventions, because there is no general consensus about the range of host plants that divides "specialist" and "generalist" feeders. Moreover, the spectrum of hosts can vary geographically. For instance, several species of bruchids that are monophagous in Hungary appear to be oligophagous in Western Europe where other hosts, which do not occur in Central Europe, are available (Delobel \& Delobel, 2006). Jermy \& Szentesi (2003) record a maximum of nine host plants for both Bruchus atomarius and Bruchidius villosus, so even these are narrowly oligophagous based on the above criteria. In contrast, all the species of bruchids recorded in this study fed on one to four species of plants (Table 3). Therefore, and in general, the host spectrum of bruchids is quite narrow and, as a constraint, it underlines the deterministic organization of their assemblages. Phylogenetic analyses strengthened the taxonomical relations and host specificity of the two bruchid genera (Kergoat et al., 2004, 2007). It is generally assumed that it is the bewildering richness of chemical plant constituents (Southon et al., 1994) that plays an important role in host specificity (Schoonhoven et al., 1998).

The values of the multiple host dissimilarity index (ES) corroborated the above and shed further light on host specificity. First, it measures the host specialization of the whole bruchid assemblage reared from the samples of leguminous plants (0.60). Its value substantially differed from the one calculated on the basis of the data in the literature (0.42). The reason for the difference was the faunistic survey of Jermy \& Szentesi (2003) that was longer and more thorough, whereas our study was restricted to 4 years and to specific habitats. Second, concerning the host specializations of the bruchid genera the $E S$-values show an opposite trend to that of the published data: species of Bruchus seem to be more specialized than those of Bruchidius. We think that the low incidence of the habitat-specialist and "widely" oligophagous $B u$. atomarius in our samples, and the presence of two Trifolium species (T. repens and $T$. incarnatum) each fed on by 3 species of Bruchidius, but not recorded by Jermy \& Szentesi (2003), can account for difference in the $E S$-values.

\section{Non-native species}

The detection of non-native species of insects (hypothesis c) in the bruchid seed predator guild highlights the possible role of transport in their distribution (Table 2 ). With the exception of those with a long colonization history in the Palearctic region, including Hungary, such as: Amorpha fruticosa-A. pallidipennis (Szentesi, 1999), Pisum sativum-Bu. pisorum, and Vicia pannonica-Bu. rufimanus (Bridwell \& Bottimer, 1933), all non-native species can be considered recent introductions. The establishment of an allochthonous species does not require the presence of the host plant because (1) there might be alternative or secondary hosts present in the vegetation along highways sufficient to sustain viable populations of polyphagous herbivorous species, and (2) oligophagous species may colonize hosts with a scattered occurrence along highways. We randomly found such species relations (Albizia julibrissinBi. terrenus, Cercis siliquastrum-Bi. siliquastri, or Gleditsia triacanthos-Megabruchidius tonkineus/M. dorsalis) despite not systematically searching for them. Some of these woody species may have spread unaided in the landscape, or are relatively preferred ornamental species in urban surroundings (e.g. Cercis siliquastrum and Albizia julibrissin). Introduced species of bruchids seemingly did not colonize native species of herbaceous leguminous plants because no new bruchid colonists were found during the four-year long survey. There are 17 species of bruchids in Western and Mediterranean countries that could live in Hungary where their 24 species of leguminous host plants occur (Delobel \& Delobel, 2006). So far none of them have been found. Although we did not investigate the role of transport in promoting bruchid introductions, the occurrence of new species cannot be ruled out in the future due to the effects of climate change and the ever-increase in road transport. Ecotones are locations at which the effects of climate change can be followed (Risser, 1993). Indeed, the presence of non native species of scale insects in Hungary is associated with such factors (Kozár \& Nagy, 1986; Kozár, 2009). The invasive species of bruchids that have been recorded are Asian (Bi. siliquastri, M. tonkineus/M. dorsalis) and North-American (A. pallidipennis) and so far neither their origin (Wendt, 1981; Jermy et al., 2002; Kergoat et al., 2007) or climatic factors have been implicated in their presence in Hungary. Contrary to the above, however, members of local bruchid assemblages, e.g., Bi. varius, which normally feed on common leguminous species like Trifolium repens and T. pratense, readily colonized Trifolium incarnatum that is a component of the seed-mix that was widely used to replant the slopes along the sides of the south-western part of the M7 highway. T. incarnatum is a native of the Hungarian flora, which, however, provided new opportunities for autochthonous bruchid colonization due to its recent increase in areas where it was not previously present. 


\section{The manifold effects of mowing}

The influence of mowing on the formation of bruchid assemblages is thought to result in artificially maintained metapopulation dynamics. Host patches are in the continuous process of regrowth/re-establishment and extinction following mowing, and so are seed predators. Host plants capable of tolerating or escaping mowing are able to mature some pods or flower heads, thereby provide food patches for seed predators. They in turn, use their good dispersal abilities to colonize the remaining host patches in nearby unmown areas. Although, our study is not experimental, the results are similar to those of Kruess \& Tscharntke (2000). They studied a leguminous host-insect seed predator system in different sized plots of their host (Vicia sepium). The specialised bruchid seed predator (Bu. atomarius) was present even in the smallest plot, while the fragmentation resulted in the extinction of the generalist species. The removal of plant patches by mowing is analogous to a decrease in the size of the host plant plots. The specialist bruchid seed predators of the Trifolium hosts were collected by both sweep-netting and by emergence from samples of Trifolium fragiferum or T. repens collected from plots as small as $1 / 16 \mathrm{~m}^{2}$.

The effect of mowing (fragmentation) is manifold and also raises concerns about conservation; among others it disrupts higher-order trophic (Herbst et al., 2013) or mutualistic (Christianini \& Oliveira, 2013) relations. Similar to the case described by Christianini \& Oliveira (2013), it was observed that mowing not only removed leguminous species of plants by locally decreasing bruchid species richness, but also affected entire trophic chains (Á. Szentesi, pers. obs.). Regrowth and production of pods following mowing was almost nil, because there was at least another mowing . Therefore, bruchids have to recolonize such sites each year.

Mowing also influences the growth form and species composition of vegetation at service areas. Most perennial species of leguminous plants of low stature survive, quickly flower again and their patch sizes may even increase (Trifolium fragiferum, T. repens, and T. hybridum). Obviously, the composition and viability of the seed bank will also be affected, which may have consequences for species composition. However, it is more probable that mowing allows plants to escape seed predation altogether, as it removes flowers and pods, and even if the plant re-sprouts, there are no predators to eat the seeds (most bruchid seed predators have one generation per year). The same is true of predator-prey and host-parasite interactions. Kruess \& Tscharntke (2000) found that the presence of both a generalist seed predator and its parasitoids was negatively influenced by a decrease in area.

Sloping sides along highways also affect plant distribution. On the one hand, a slope favours the development of large, more-or-less homogeneous patches of plants. For instance, the sowing of seed of the annual Trifolium incarnatum on the slopes along the sides of the M7 highway, resulted in the development of very large patches along draining ditches at the base of the slopes, because seeds were washed there by rain water. On the other hand, slopes close to mowed areas can serve as reservoirs for recolonization as they are less frequently mown than service areas.

\section{CONCLUSIONS}

It is concluded that (1) the composition of bruchid assemblages in highway ecotones depends on the presence of species of leguminous plants that can tolerate or escape the effect of mowing; (2) the organization of the seed predator guild depends on the high level of host specialisation of its members, and (3) due to mowing, bruchid assemblages continuously face local extinction and the need to recolonize patches of leguminous host plants.

ACKNOWLEDGEMENTS. The authors are grateful to the late F. Kozár, who enthusiastically initiated and supported highway research. É. Szita, R. Lupták, Z. Nagy and G. Tholt significantly helped with the field work. T. Borsics substantially improved the quality of the text. Several reviewers made helpful suggestions. Financial support was provided by OTKA 83829 . Thanks are due to the management personnel of highways for providing the permissions for us to do this work.

\section{REFERENCES}

Bridwell J.C. \& Bottimer L.J. 1933: The hairy-vetch bruchid, Bruchus brachialis Fahraeus, in the United States. - J. Agr. Res. 46: 739-751.

BROWN J.H. 1987: Variation in desert rodent guilds: patterns, processes, and scales. In Gee J.H.R. \& Giller P.S. (eds): Organization of Communities Past and Present. Blackwell, London, pp. 185-204.

Cadenasso M.L., Pickett S.T.A., Weathers K.C., Bell S.S., Benning T.L., Carreiro M.M. \& Dawson T.E. 2003: An interdisciplinary and synthetic approach to ecological boundaries. - BioScience 53: 717-722.

Cantrell R.S., Cosner C. \& Fagan W.F. 2002: Habitat edges and predator-prey interactions: effects on critical patch size. Math. Biosci. 175: 31-55.

Christianini A.V. \& Oliveira P.S. 2013: Edge effects decrease ant-derived benefits to seedlings in a Neotropical savanna. Arthr-Plant Int. 7: 191-199.

CRAWLEY M.J. 2000: Seed predators and plant population dynamics. In Fenner M. (ed.): Seeds. The Ecology of Regeneration in Plant Communities. CABI, Wallingford, pp. 167-182.

Delobel B. \& Delobel A. 2006: Dietary specialization in European species groups of seed beetles (Coleoptera: Bruchidae: Bruchinae). - Oecologia 149: 428-443.

DidHAm R.K. 1998: Altered leaf-litter decomposition rates in tropical forest fragments. - Oecologia 116: 397-405.

Diserud O.H. \& ØDEgaARD F. 2007: A multiple-site similarity measure. - Biol. Lett. 3: 20-22.

Entsminger G.L. 2014: EcoSim Professional: Null Modeling Software for Ecologists. Ver. 1. Acquired Intelligence Inc., Kesey-Bear \& Pinyon, Montrose, CO 81403. URL: http://www. garyentsminger.com/ecosim/index.htm

Ewers R.M. \& Didham R.K. 2008: Pervasive impact of largescale edge effects on a beetle community. — Proc. Natn. Acad. Sci. USA 105: 5426-5429.

FAGAN W.F., Fortin M.J. \& Soykan C. 2003: Integrating edge detection and dynamic modeling in quantitative analyses of ecological boundaries. — BioScience 53: 730-738.

Forman R.T.T., Sperling D., Bissonette J.A., Clevenger A.P., Cutshall C.D., Dale V.H., Fahrig L., France R., Goldman 
C.R., Heanue K. et Al. 2003: Road Ecology: Science and Solutions. Island Press, Washington, D.C., 504 pp.

Frenzel M. \& BrandL R. 1998: Diversity and composition of phytophagous insect guilds on Brassicaceae. - Oecologia 113: 391-399.

Gosz J.R. 1993: Ecotone hierarchies. — Ecol. Appl. 3: 369-376.

Gotelli N.J. \& Graves G.R. 1996: Null Models in Ecology. Smithsonian Institution Press, Washington and London, 368 pp.

GYÖRGY Z. \& MERKL O. 2005: Seed beetles preserved in the Savaria Museum, Hungary, with a National Checklist of the family (Coleoptera: Bruchidae). — Praenorica (Folia Hist.-Nat.) 8: $65-78$.

HADDAD N.M. 1999: Corridor use predicted from behaviors at habitat boundaries. - Am. Nat. 153: 215-227.

Herbst C., Waeschke N., Barto E.K., Arnold S., Geuss D., Halboth I., Reschie S., Saenger J., Meiners T. \& Obermaier E. 2013: Land use intensification in grasslands: higher trophic levels are more negatively affected than lower trophic levels. - Entomol. Exp. Appl. 147: 269-281.

JERMY T. \& SzENTESI Á. 2003: Evolutionary aspects of host plant specialisation - a study on bruchids (Coleoptera: Bruchidae). - Oikos 101: 196-215.

Jermy T., Szentesi Á. \& Anton K.W. 2002: Megabruchidius tonkineus (Pic, 1904) (Coleoptera: Bruchidae) first found in Hungary. - Folia Entomol. Hung. 63: 49-51.

Kergoat G.J., Delobel A. \& Silvain J.F. 2004: Phylogeny and host-specificity of European seed beetles (Coleoptera, Bruchidae), new insights from molecular and ecological data. - Mol. Phylogenet. Evol. 32: 855-865.

Kergoat G.J., Delobel P. \& Delobel A. 2007: Phylogenetic relationships of a new species of seed-beetle infesting Cercis siliquastrum L. in China and in Europe (Coleoptera: Chrysomelidae: Bruchinae: Bruchini). - Ann. Soc. Entomol. Fr. 43: 265-271.

Kergoat G.J., Silvain J.F., Delobel A., Tuda M. \& Anton K.W. 2007: Defining the limits of taxonomic conservatism in hostplant use for phytophagous insects: Molecular systematics and evolution of host-plant associations in the seed beetle genus Bruchus Linnaeus (Coleoptera: Chrysomelidae: Bruchinae). Mol. Phylogenet. Evol. 43: 251-269.

Kiss B., Lengyel G., Nagy Z. \& KÁrpáti Z. 2013: First record of spotted wing drosophila [Drosophila suzukii (Matsumura, 1931)] in Hungary. — Növényvédelem 49: 97-99 [in Hungarian, English abstr.].

Knapp M., Saska P., Knappova J., Vonicka P., Moravec P., Kurka A. \& ANDEL P. 2013: The habitat-specific effects of highway proximity on ground-dwelling arthropods: implications for biodiversity conservation. - Biol. Conserv. 164: 22-29.

KozÁR F. 2009: Scale species (Hemiptera, Coccoidea) and climate change studies on Hungarian highways. - Növényvédelem 45 577-588 [in Hungarian, English abstr.].

KozÁR F. \& NAGY D.A. 1986: The unexpected northward migration of some species of insects in Central Europe and the climatic changes. - Anz. Schädlingskd. Pfl. 59: 90-94.

KozÁr F., Szita É., Fetykó K., Neidert D., Konczné Benedicty Z. \& Kiss B. 2013: Scale Insects, Highways, Climate. Insect Studies on Highways, Related to Climate Change. Instructions and Results. MTA ATK Növényvédelmi Intézet, Budapest, 215 pp. [in Hungarian].

Kruess A. \& TscharntKe T. 2000: Species richness and parasitism in a fragmented landscape: experiments and field studies with insects on Vicia sepium. — Oecologia 122: 129-137.
Lehsten V. \& Harmand P. 2006: Null models for species co-occurrence patterns: assessing bias and minimum iteration number for the sequential swap. - Ecography 29: 786-792.

Lengyel G., Orosz S., Kiss B. \& KáRpátr Z. 2013: New records and present status of the invasive spotted wing drosophila, Drosophila suzukii, Matsumura (Diptera) in Hungary. - Acta Zool. Acad. Sci. Hung. 61: 73-80.

Magurran A.E. 2004: Measuring Biological Diversity. Blackwell, Malden, $256 \mathrm{pp}$.

Marini M.A., Robinson S.K. \& Heske E.J. 1995: Edge effects on nest predation in the Shawnee National Forest, Southern Illinois. - Biol. Conserv. 74: 203-213.

MatošEvić D. \& ŽIVković I. 2013: Alien phytophagous insect and mite species on woody plants in Croatia. - Sumar. List 137: 191-205 [in Croatian, English abstr.].

May R.M. 1990: How many species? — Philos. Trans. Roy. Soc. (B) 330: 293-304.

MuÑoz P.T., TorRes F.P. \& Megías A.G. 2015: Effects of roads on insects: a review. - Biodivers. Conserv. 24: 659-682.

Peters D.P.C., Gosz J.R. \& Collins S.L. 2009: Boundary dynamics in landscapes. In Levin S.A. (ed.): The Princeton Guide to Ecology. Princeton University Press, Princeton and Oxford, pp. 458-463.

Pullin A.S. 2002: Conservation Biology. Cambridge University Press, Cambridge, 345 pp.

RISSER P.G. 1993: Ecotones at local to regional scales from around the world. - Ecol. Appl. 3: 367-368.

Roques A. \& BeEnen R. 2010: Leaf and seed beetles (Coleoptera, Chrysomelidae). In Roques A., Kenis M., Lees D., Vaamonde C.L., Rabitsch W., Rasplus J.Y. \& Roy D. (eds): Alien Terrestrial Arthropods of Europe. Pensoft, Sofia, pp. 267-292.

SCHOENER T.W. 1986: Overview: kinds of ecological communities - Ecology becomes pluralistic. In Diamond J. \& Case T.J. (eds): Community Ecology. Harper \& Row, New York, pp. 467-479.

SchoOnhOVEn L.M., Jermy T. \& van LoOn J.A.A. 1998: InsectPlant Biology. From Physiology to Evolution. Chapman \& Hall, London, 406 pp.

Schultz C.B., Franco A.M.A. \& Crone E.E. 2012: Response of butterflies to structural and resource boundaries. - J. Anim. Ecol. 81: 724-734.

ŠERÁ B. 2008: Road vegetation in Central Europe - an example from the Czech Republic. — Biologia 63: 1085-1088.

Simberloff D., Stone L. \& Dayan T. 1999: Ruling out a community assembly rule: the method of favored states. In Weiher E. \& Keddy P. (eds): Ecological Assembly Rules. Perspectives, Advances, Retreats. Cambridge University Press, Cambridge, pp. 58-74.

Southon I.W., Bisby F.A., Buckingham J., Harborne J.B. \& ZARUCCHI J.L. 1994: Phytochemical Dictionary of the Leguminosae. Chapman \& Hall, London, 1808 pp.

StatSoft Inc. 2003: Statistica (Data Analysis Software System). Ver. 6. URL: http://www.statsoft.com

Stone L. \& RoBerTs A. 1990: The checkerboard score and species distributions. - Oecologia 85: 74-79.

Strayer D.L., Power M.E., Fagan W.F., Pickett S.T.A. \& BelNAP J. 2003: A classification of ecological boundaries. - BioScience 53: 723-729.

STRONG D.R. 1982: Harmonious coexistence of hispine beetles on Heliconia in experimental and natural communities. - Ecology 63: 1039-1049.

SzENTESI Á. 1999: Predispersal seed predation of the introduced false indigo, Amorpha fruticosa L. in Hungary. - Acta Zool. Acad. Sci. Hung. 45: 125-141. 
Szentesi Á. \& Jermy T. 1995: Predispersal seed predation in leguminous species: seed morphology and bruchid distribution. - Oikos 73: 23-32.

SZEnTESI Á. \& Jermy T. 2003: Pre-dispersal seed predation and seed limitation in an annual legume. - Basic Appl. Ecol. 4 207-218.

Szentesi Á., Schmera D. \& Jermy T. 2006: Spatial and temporal organisation of the pre-dispersal seed predator guild in a perennial legume, Vicia tenuifolia. - Ecol. Entomol. 31: 114-122.

UlRICH W. 2008: Pairs - a FORTRAN Program for Studying Pair-wise Species Associations in Ecological Matrices. Ver. 1. URL: http://www.keib.umk.pl

Ree R., Jaeger J.A.G., Grift E.A. \& Clevenger A.P. 2011: Effects of roads and traffic on wildlife populations and landscape function: road ecology is moving toward larger scales. - Ecol. Soc. 16: 48.

Weiner E. \& Keddy P. 1999: Ecological Assembly Rules. Perspectives, Advances, Retreats. Cambridge University Press, Cambridge, 418 pp.
WENDT H. 1981: Eine für Südost-Europa neue Samenkäfer-Art (Coleoptera: Bruchidae). — Folia Entomol. Hung. 34: 223226.

WIENS J.A. 2000: Ecological heterogeneity: an ontogeny of concepts and approaches. In Hutchings M.J., John EA. \& Stewart A.J.A. (eds): The Ecological Consequences of Environmental Heterogeneity. Symposia of the British Ecological Society. Blackwell Science, Cambridge, pp. 9-31.

WiEns J.A., CRAwFord C.S. \& Gosz J.R. 1985: Boundary dynamics - a conceptual-framework for studying landscape ecosystems. - Oikos 45: 421-427.

Yus-Ramos R., Ventura D., Bensusan K., Coello-Garcia P., György Z. \& Stojanova A. 2014: Alien seed beetles (Coleoptera: Chrysomelidae: Bruchinae) in Europe. - Zootaxa 3826: 401-448.

ZwÖLFER H. 1988: Evolutionary and ecological relationships of the insect fauna of thistles. - Annu. Rev. Entomol. 33: 103122.

Received April 12, 2017; revised and accepted September 19, 2017 Published online November 9,2017 